\title{
PENERAPAN STUDENT FASILITATOR AND EXPLAINING TERHADAP KETERAMPILAN BERBICARA STKIP PGRI SUMATERA BARAT
}

\author{
Risa Yulisna ${ }^{1}$, Afrini Rahmi ${ }^{2}$ \\ $\underline{\text { risa@stkip-pgri-sumbar.ac.id }}^{1}$, afrini@stkip-pgri-sumbar.ac.id $^{2}$ \\ STKIP PGRI SUMATERA BARAT
}

\begin{abstract}
Abstrak
Penelitian ini dilatarbelakangi oleh pentingnya keterampilan berbicara bagi siswa guru sebagai calon pendidik. Keterampilan berbicara yang sangat minim mempengaruhi kemampuan mahasiswa untuk menjelaskan materi atau materi pelajaran dalam perkuliahan serta kemampuan menjelaskan materi di kelas nanti. Penelitian ini bertujuan untuk meningkatkan kemampuan siswa dalam menjelaskan dengan menggunakan model pembelajaran Student Fasilitator And Explaining. Jenis penelitian ini adalah penelitian kuantitatif dengan metode penelitian eksperimen. Populasi dalam penelitian ini adalah 220 mahasiswa angkatan 2016. Sampel penelitian dipilih dengan menggunakan teknik purposive sampling. Instrumen penelitian berupa tes kinerja dan angket. Hasil penelitian ini menunjukkan bahwa penggunaan model pembelajaran Student Facilitator And Explaining Center (SFAE) mampu meningkatkan keterampilan berbicara.

Kata kunci: kemampuan berbicara, model pembelajaran, Student Fasilitator
\end{abstract} And Explaining

\begin{abstract}
This research is motivated by the importance of speaking skills for teacher students as prospective educators. Very minimal speaking skills affect the ability of students to explain the material or subject matter in lectures and the ability to explain material in class later. This study aims to improve students' ability to explain by using the Student Facilitator And Explaining learning model. This type of research is quantitative research with experimental research methods. The population in this study were 54 students of the 2016 Indonesian Language and Literature Education Study Program. The research sample was selected using a purposive sampling technique. The research instruments are in the form of performance tests and questionnaires. The results of this study indicate that the use of the Student Facilitator And Explaining Center (SFAE) learning model is able to improve speaking skills.

Keywords: speaking skills, learning models, Student Facilitator and Explaining
\end{abstract}




\section{PENDAHULUAN}

Keterampilan berbicaramerupakan salah satu modal utama mahasiswa calon pendidik untuk dapat mengajarkan keterampilan berbicara di sekolah. Pengajaran keterampilan berbicara di sekolah merupakan bagian yang terintergrasi dengan pembelajaran kaidah kebahasaan. Oleh karena itu, keterampilan berbicara menjadi salah satu cara mahasiswa calonpendidik untuk dapat memahami strategi pengajaran keterampilan berbicara di sekolah.

Namun pada kenyataannya, sistem perkuliahan yang menggunakan diskusi kelompok cenderung membuat mahasiswa tidak mampu menguasai materi dengan baik. Diskusi kelompok yang telah dilakukan hanya memancing mahassiswa yang aktif saja untuk berpartisipasi. Padahal hakikat diskuisi sebenarnya menurut Arief dan Munaf (2003) diskusi berasal dari bahasa latin yaitu discusio atau discusium yang artinya bertukar pikiran. Akan tetapi belum tentu setiap kegiatan bertukar pikiran dapat dikatakan berdiskusi. Diskusi pada dasarnya merupakan suatu bentuk tukar pikiran yang teratur dan terarah, baik dalam kelompok kecil maupun kelompok besar dengan tujuan untuk mendapatkan suatu pengertian, kesepakatan, dan keputusan bersama mengenai suatu masalah. Proses diskuisi yang dilaksanakan di kelas hanya berbicarakan makalah oleh pemateri dalam masingmasing kelompok. Akibat kondisi tersebut, forum diskusi yang seharusnya menjadi media untuk untuk mengukur penguasaan materi tidak efektif.

Salah satu cara yang dapat digunakan untuk dapat mengukur kemampuan mahasiswa dalam berbicara dan menguasai materi dalam presentasi di kelas adalah dengan penggunaan model pembelajaran. Secara etimologi model merupakan pola atau acuan dari sesuatu yang akan dihasilkan. Model adalah suatu perencanaan atau suatu pola yang di gunakan sebagai pedoman dalam merencanakan pembelajaran. Menurut Suprijono (2009:46) Model pembelajaran ialah pola yang digunakan sebagai pedoman dalam merencanakan pembelajaran dikelas maupun tutorial. Model pembelajaran adalah bentuk pembelajaran yang tergambar dari awal sampai akhir yang disajikan secara khas oleh guru di kelas. Model pembelajaran adalah pola atau rencana yang dapat digunakan untuk mengoperasikan kurikulum. Merancang materi pembelajaran, dan untuk membimbing belajar dalam setting kelas atau lainnya.

Model pembelajaran pola pembelajaran dalam tutorial sebagai pedoman dalam melaksanakan pembelajaran dan untuk menentukan perangkat-perangkat pembelajaran termasuk di dalamnya buku-buku, film, computer, kurikulum, dan lain-lain. Model pembelajaran yaitu suatu perencanaan atau suatu pola yang digunakan sebagai pedoman yang digunakan dalam merencanakan pembelajaran. Sagala (2005) mengemukakan bahwa model pembelajaran adalah kerangka konseptual yang melukiskan prosedur yang sistematis dalam mengorganisasikan pengalaman belajar mahasiswa untuk mencapai tujuan belajar tertentu dan berfungsi sebagai pedoman bagi perancang pembelajaran dan pengajar dalam merencanakan dan melaksanakan aktivitas belajar mengajar.Melalui model pembelajaran pengajar dapat membantu mahasiswa mendapatkan informasi, ide, keterampilan, cara berfikir, dan mengekspresikan ide. Model pembelajaran berfungsi pula sebagai pedoman bagi para perancang pembelajaran dan para guru dalam merencanakan aktivitas belajar mengajar. 
Berdasarkan uraian tentang pengertian dan hakikat model pembelajaran dapat dikatakan bahwa model pembelajaran memiliki ciri-ciri sebagai berikut:

a. Berdasarkan teori pendidikan dan teori belajar dari para ahli tertentu. Model ini dirancang untuk melatih partisipasi mahasiswa dalam kelompok secara demokratis.

b. Mempunyai misi atau tujuan pendidikan tertentu, misalnya model pembelajaran berpikir induktif dirancang untuk mengembangkan proses berpikir induktif.

c. Dapat dijadikan pedoman untuk perbaikan kegiatan belajar mengajar di kelas.

d. Memiliki bagian-bagian model yang disebut (1) urutan langkah-langkah pembelajaran (syntax), (2) adanya prinsip-prinsip reaksi, (3) sistem sosial, (4) sistem pendukung. Keempat hal tersebut merupakan pedoman praktis untuk melasksanakan suatu model pembelajaran.

e. Memiliki dampak sebagai akibat terapan model pembelajaran. Dampak tersebut meliputi dampak pembelajaran, yaitu hasil belajar yang dapat diukur; dan dampak pengiring, yaitru hasil belajar jangka panjang.

f. Membuat persiapan mengajar (desain instruksional) dengan pedoman model pembelajaran yangh dipilihnya.

Model pembelajaran yang dapat membantu mahasiswa aktif adalah Student Fsilitator And Explaining (SFAE). Model pembelajaran ini mampu memotivasi, meningkatkan aktivitas belajar mahasiswa dan memberi semangat kepada mahasiswa agar lebih giat dan memiliki rasa tanggung jawab dalam menguasai materi/pokok pembahasan. Model pembelajaran Student Facilitator and Explaining (SFAE) merupakan model pembelajaran yang menuntun mahasiswa untuk mampu mempresentasikan ide atau pendapat pada rekan mahasiswa lainnya.

Menurut Suprijono (2009), model pembelajaran Student Facilitator And Explaining merupakan salah satu bagian dari model pembelajaran klasikal. Model Pembelajaran Student Facilitator and Explaining(SFAE) merupakan model pembelajaran dimana mahasiswa atau mahasiswa belajar mempresentasikan ide atau pendapat pada rekan mahasiswa lainnya. Model pembelajaran ini efektif untuk melatih mahasiswa berbicara untuk menyampaikan ide atau gagasan atau pendapatnya sendiri. Mahasisawa mempunyai banyak kesempatan untuk mengolah informasi dan meningkatkan keterampilan berkomunikasi.

Menurut Taniredja (2013) model pembelajaran Student Facilitator and Explaining merupakan model pembelajaran dimana mahasiswa/mahasiswa belajar mempresentasikan ide/pendapat pada rekan mahasiswa lainnya. Model pembelajaran ini dapat membantu mahasiswa untuk melatih kemampuan berbicara dan menyampaikannya dalam diskusi kelompok.

Keunggulan model pembelajaran Student Facilitator And Explaining (SFAE) dibanding model yang lain adalah mahasiswa dituntut untuk mampu bertanggung jawab meberikan pemahamahan kepada rekannya terhadap materi yang dipahami. Setiap mahasiswa memiliki kesempatan yang sama untuk tampil ke depan kelas memberikan penjelasan kepada semua rekannya tentang materi yang dikuasainya. Dengan demikian, seluruh mahasiswa punya kesempatan yang sama untuk melatih dan membiasakan diri menguasai konsep dasar pembahasan 
serta memiliki kemampuan menjelaskan kepada rekan-rekannya di dalam proses perkuliahan. Latihan dan pembiasaan tersebut secara langsung akan membentuk kemampuan penguasaan materi dan kemampuan menjelaskan yang lebih baik secara bertahap. Dalam bentuk jangka panjang, mahasiswa akan mampu menguasai materi dengan baik. Cara penguasaan materi untuk dapat melaksanakan model SFAE ini adalah dengan melatih kemampuan berbicara agar dapat menjelaskan dengan mudah.

Pelaksanaan model Student Facilitator And Explaining, ada beberapa langkah. Secara umum langkah-langkah model pembelajaran Student Facilitator And Explaining sebagai berikut.

1. Menyampaikan topik pembahasan

2. Menentukan poin-poin pembahasan materi

3. Memberikan kesempatan kepada mahasiswa untuk menyampaiakan penguasaan materi terhadap topik pembahasan baik melalui bagan, peta konsep maupun yang lainnya dalam bentuk presentasi

4. Menyimpulkan ide/pendapat dari dari hasil presentasi yang ditampilkan

5. Mengulas dan membahas kembali materi yang telah disajikan mahasiswa

6. Penutup

Dapat disimpulkan langkah-langkah model Student Facilitator And Explaining yaitu: pembukaan (apersepsi dan pemberian motivasi), guru menyampaikan kompetensi yang akan dicapai, mendemonstrasikan atau menyajikan materi secara ringkas, memberikan kesempatan kepada mahasiswa untuk mempresentasikan kepada mahasiswa lainya melalui media (peta konsep, gambar, maupun bagan), menyimpulkan ide atau pendapat mahasiswa, menerangkan materi pembelajaran saat itu dan meluruskan ide atau pendapat mahasiswa, menutup pembelajaran. Pada saat presentasi, mahasiswa yang lain juga dapat memberikan kontribusi dalam bentuk ulasan pendapat terhadap topik yang dibahas. Hal tersebut secara tidak langsung memancing mahasiswa untuk aktif berpartisipasi dalam perkuliahan yang dilaksanakan.

\section{METODOLOGI}

Jenis penelitian ini adalah penelitian kuantitatif-kualitatif dengan metode peneliti deskripstif.data kuantitatif diberikan untuk mengukur kemampuan berbicara mahasiswa dengan unjuk kerja berupa presentasi yang dinilai dari segi kebahasaan dan nonkebahasan.

Data kuantitatif digunakan untuk mengukur kemampuan berbicara dengan menggunakan tes unjuk kerja. Data kualitatif adalah data hasil pengukuran kemampuan berbicara yang dinarasikan dengan mengaitkan pada lingkungan kegiatn belajar.

Populasi adalah keseluruhan objek penelitian. Sementara menurut Sugiyono (2007), populasi adalah wilayah generalisasi yang terdiri atas: obyek/subyek yang mempunyai kualitas dan karakteristik tertentu yang ditetapkan oleh peneliti untuk dipelajari dan kemudian ditarik kesimpulannya. Populasi bukan sekedar jumlah objek/subjek yang dipelajari, tetapi meliputi sifat/ karakteristik yang dimiliki objek/subjek. Menurut Sugiyono (2007) sampel merupakan bagian dari jumlah 
dankarakteristik yang dimiliki oleh populasi tersebut. Oleh karena itu dibutuhkan teknik pengambilan sampel.

Populasi dalam penelitian ini mahasiswa Program studi pendidikan Bahasa dan Keterampilan berbicara Indonesia angkatan 2016 sebanyak 220 orang. Sampel penelitian adalah sesi D sebanyak 29 orang. Sampel penelitian dipilih dengan menggunakan teknik purposive sampling.

\section{HASIL PENELITIAN DAN PEMBAHASAN}

Penelitian ini dilaksanakan sebanyak tiga kali pertemuan. Peneliti memberikan pretes untuk pertemuan pertama. Pretes diberikan untuk mengukur kemampuan awal berbicara mahasiswa dengan bentuk tes pilihan ganda. Pada bagian akhir tatap muka pertemuan ke tiga mahasiswa juga diberikan postes. Untuk lebih rinci akan diuraikan dalam beberapa tahap berikut ini.

\subsection{Pertemuan I}

Pada pertemuan pertama mahasiswa diberikan kesempatan untuk presentasi materi dalam diskusi kelompok. Diskusi kelompok yang dilaksanakan sesuai prosedur diskusi yang biasa dilakukan. Masing-masing anggota kelompok melaksanakan fungsi masing-masing dalam kelompok. Audiens juga memberikan respon terhadap pelaksanaan diskusi. Pretes dilaksanakan di akhir perkuliahan. Hasil pretes kemampuan berbicara tersebut dapat terlihat dalam tabel berikut ini.

\section{Tabel 1: Skor Hasil Tes Pretes}

\begin{tabular}{|c|c|c|}
\hline Interval & Frekuensi & Persentase \\
\hline $79-83$ & 3 & $10,34 \%$ \\
$74-78$ & 4 & $13,79 \%$ \\
$69-73$ & 5 & $17,24 \%$ \\
$64-68$ & 7 & $24,14 \%$ \\
$59-63$ & 3 & $10,34 \%$ \\
$53-58$ & 7 & $24,14 \%$ \\
\hline Total & 29 & $100 \%$ \\
\hline
\end{tabular}

Berdasarkan nilai pretest keterampilan berbicara siswa di atas dihitung mean, modus, dan median. Perkuliahan diakhiri dengan menyimpulkan materi belajar secara bersama-sama dan mengerjakan soal evaluasi. Pemberian soal evaluasi tersebut dilakukan untuk mengetahui tingkat kepahaman siswa terhadap materi. Hasil evaluasi pertemuan 1 pada perlakuan I memperoleh nilai rata-rata sebesar 64,45 .

\subsection{Pertemuan II}

Pada peretemuan ke dua ini, perlakuan diterapkan dengan menggunakan model pembelajaran SFAE. Langkah-langkah dalam penerapan Model Student Facilitator And Explaining dalam perkuliahan adalah sebagai berikut.

\section{a. Pembukaan}

Memulai perkuliahan dengan melakukan orientasi, bertujuan untuk memusatkan perhatian mahasiswa pada pembelajaran yang akan disampaikan selajutnya apersepsi, setelah melakukan orientasi selanjutya pengajar melakukan 
apersepsi yang bertujuan utuk mengingatkan kembali tentang prosedur penyajian topik bahasan..

b. Pengajar menyampaikan kompetensi yang ingin dicapai.

Sebelum pembelajaran dimulai, setiap penyaji terlebih dahulu akan menyampaikan topik pembahasan yang akan disampaikan dalam presentasi.

\section{c. Pengajar mendemonstrasikan atau menyajikan materi}

Penyaji menguraikan materi dengan model Student Facilitator And Explaining. Pengajar menggunakan model Student Facilitator And Explaining dalam proses pembelajaran. Pengajar menerangkan perkuliahan terlebih dahulu setelah itu mahasiswa disuruh secara bergantian tampil di depan kelas dengan media yaitu berupa suatu materi dan menjelaskan lagi di depan kelas tentang isi materi yang telah dijelaskan.

\section{d. Memberikan kesempatan kepada peserta didik untuk mempresentasekan ide dan pendapatnya kepada peserta didik}

Pengajar menerangkan pembelajaran secara ringkas kemudian meminta mahasiswauntuk tampil di depan kelas menerangkan dengan media yang telah ada, Ketiga, jika ada temannya yang tidak mengerti dan bertanya dan peserta didik yang tampil akan mengulang menjelaskan kembali, jika belum juga mengerti yang akan membantu menjelaskan tentang materi tersebut. Keempat memberi kuis yang dikerjakan secara mandiri. Hal ini bertujuan untuk menunjukkan yang telah diperoleh mahasiswa selama belajar dan hasil kuis ini digunakan sebagai nilai perkembangan individu. dan yang terakhir penghargaan kepada mahasiswa yang menguasai dan tampil bagus menjelaskan perkuliahan. Pengajar menyuruhkan untuk tampil di depan kelas, kalau ada teman yang kurang atau tidak mengerti maka diminta untuk membantunya sampai teman tersebut mengerti, setelah itu kami diberi pertanyaan yang mana dijawab sendiri-sendiri.

\section{e. Pengajar menyimpulkan ide dan pendapat dari peserta didik}

Setelah mahasiswa tampil di depan kelas menerangkan dengan media yang telah ada, jika ada temannya yang tidak mengerti dan bertanya maka pengajar membantu meberikan penjelasan. Berdasarkan wawancara dan observasi diatas, model Student Facilitator And Explaining sangat menyenangkan bagi mahasiswa. Untuk mewujudkan proses pembelajaran yang menyenagkan pengajar harus mampu merancang pembelajaran yang baik, memilih materi yang tepat, serta memilih dan mengembangkan strategi yang dapat melibatkan mahasiswa secara optimal.

Dari pernyataan di atas, menunjukkan bahwa pengajar dalam mengajar telah menerapkan pembelajaran yang menyenangkan terhadap mahasiswa dengan cara memberi selingan intermezzo agar mahasiswa tidak jenuh selama proses pembelajaran berlangsung.

Dari hasil wawancara di atas, bahwa pengajar mempunyai strategi dalam berinteraksi dengan mahasiswadengan cara bersikap ramah dan tidak menggunakan kekerasan. Pembelajaran Student Facilitator And Explaining bertujuan untuk jauh lebih meningkatkan kesempatan mahasiswadalam berbicara, mengungkapkan ide-ide yang mereka punya dan memotivasi temannya untuk belajar lebih rajin dan bersemangat kembali. Tujuan utama dalam model Student 
Facilitator And Explaining adalah agar mahasiswabelajar tampil didepan kelas dan meningkat dalam pengajaran berbicara, berbicara, menulis, ataupun mendengarkan.

\section{f. Penutup}

Kegiatan ini dilaksanakan oleh pengajar dengan cara menarik kesimpulan dengan memberikan penekanan terhadap hal-hal penting dari materi pembelajaran. Dalam kegiatan ini pengajar juga melakukan evaluasi secara tertulis yang berupa kuis selain itu pengajar juga selalu memberikan arahan tindak lanjut arahan.

\subsection{Pertemuan III}

Pada pertemuan ke tiga ini mahasiswa diminta untuk langsung tampil menjelaskan ke depan kelas. Mahasiswa yang telah dipilih secara acak untuk tampil telah mempersiapkan diri untuk tampil ke depan dengan menggunakan media yang sudah dipersiapkan. Setiap mahasiswa yang ditunjuk tampil ke depan kelas dengan semangat, walaupun ada beberapa mahasiswa yang masih terkesan ragu-ragu ketika dipanggil. Hal ini terjadi karena kebiasaan pola diskusi kelompok yang mereka laksanakan di semua mata kuliah. Setelah tampil presentasi ke depan kelas, mahasiswa kemudian diberikan postes untuk penilaian keterampilan berbicara mereka.

Berdasarkan pembelajaran pada pertemuan ketiga ini, siswa terlihat semakin mantap dalam meningkatkan kemampuan berbicara pemahamannya. Hal tersebut terlihat dari nilai evaluasi yang lebih tinggi dari tatap muka pembelajaran sebelum-sebelumnya. Pada pertemuan ketiga ini, mean nilai evaluasi kelas memperoleh nilai 71,90. Mahasiswa diberikan soal posttest sebanyak 25 butir. Mahasiswa yang mengikuti posttest sebanyak 25 orang. Adapun hasil posttest dikonversikan dalam tabel sebagai berikut.

Tabel 2. Skor Hasil Tes Postes

\begin{tabular}{|c|c|c|c|}
\hline No. & Interval & Frekuensi & Persentase \\
\hline 1 & $93-97$ & 3 & $9,68 \%$ \\
\hline 2 & $88-92$ & 10 & $32,26 \%$ \\
\hline 3. & $83-87$ & 11 & $35,48 \%$ \\
\hline 4. & $78-82$ & 5 & $16,13 \%$ \\
\hline 5. & $73-77$ & 2 & $6,45 \%$ \\
\hline & $\mathrm{N}$ & 31 & $100 \%$ \\
\hline
\end{tabular}

Pada interval 73-77, hanya ada dua orang yang memperoleh nilai dalam interval tersebut. Interval 73-77 merupakan interval yang paling rendah. Sedikitnya yang memperoleh skor pada interval tersebut menunjukkan adanya peningkatan kemampuan berbicara pada mahasiswa yang telah mendapatkan perlakuan dengan model pembelajaran SFAE.

Pembahasan

Menurut Taniredja (2013) model pembelajaran Student Facilitator and Explaining merupakan model pembelajaran dimana mahasiswa/mahasiswa belajar ISSN. 1979-6307 
mempresentasikan ide/pendapat pada rekan mahasiswa lainnya. Model pembelajaran ini dapat membantu mahasiswa untuk melatih kemampuan berbicara dan menyampaikannya dalam diskusi kelompok. kemampuan untuk menyampaikan ide dan pendapat dalam diskusi tersebut diperoleh dengan cara penugasan dalam bentuk kegiatan berbicara.

Langkah-langkah yang digunakan dalam model pembelajajran ini membantu memotivasi mahsiswa untuk lebih giat berbicara karena ketika presentasi, mahasiswa hanya dibantu dengan media yang dipersiapkan sebelum tampil. Mahasiswa telah diminta untuk memahami topik pembahasan yang akan ditampilkan. Penyajian materi juga tidak dalam bentuk presentasi makalah seperti dalam diskusi kelompok yang biasa dilakukan. Presentasi materi ditugaskan kepada mahasiswa secara individu, sehingga mahasiswa bertanggung jawab untuk memahami. Pemahaman mereka tersebut dibuktikan dengan kemampuan memberikan respon terhadap pertanyaan yang diajukan oleh audiens terhadap topik pembahasan yang diuraikan di depan kelas.

Mahasiswa bertanggung jawab penuh untuk mampu memberikan jawaban terhadap pertanyaan forum secara jelas dengan bahasa sendiri dan bukan dengan bahasa buku. Buku referensi dalam presentasi hanya berguna sebagai panduansajauntuk membantu mahasiswa menguraikan secara rinci disertai dengan contoh yang dekat lingkungan sekitarnya. Hal tersebut secara tidak langsung menuntut mahasiswa untuk memahami dengan jelas tentang topik yang diuraikan. Selain itu, model pembelajaran ini juga memberikan kesempatan kepada pendengar untuk dapat meberikan tanggapan dengan pemahaman mereka terhadap topik yang sama, sehingga materi menjadi lebih luas penjabarannya. Langkah terakhir berupa simpulan dari pengajar menjadi sarana untuk dapat menyimpulkan pemahaman yang berbeda terhadap topik secara lebih general. Pelakasanaan model pembelajaran ini membuat mahasiswa lebih antusias dalam proses perkuliahan karena mereka tidak mengetahui penyaji yang tampil dalam setiap tatap muka. Berbeda dengan diskusi kelompok yang biasa dilaksanakan.

Model pembelajaran SFAE ini mengharuskan mahasiswa untuk tampil ke depan kelas menjelaskan materi. Pemilihan mahasiswa secara acak secara tidak langsung membuat mahasiswa harus mempersiapkan diri untuk memahami materi dengan baik. Persiapan tersebut diperoleh dengan melatih diri untuk berbicara berbagai referensi. Kegiatan berbicara bverbagai refernsi tersebut akan membantu mahasiswa untuk dapat menjelaskan dengan baik di depan kelas saat terpilih untuk menjadi penyaji. Dengan demikian, penggunaan model pembelajaran ini mampu membuat mahasiswa untuk terampil berbicara secara cermat. Respon mahasiswa yang menunjukkan perilaku baik dari setiap pertemuan, memperkuat kesimpulan bahwa ada peningkatan pengajaran berbicara mahssiswa. Selain bukti secara perilaku, bukti lain yang menguatkan adanya peningkatan ialah hasil tes siswa yang mengalami peningkatan dari setiap siklus seperti yang telah dijelaskan pada bahasan sebelumnya.

\section{KESIMPULAN DAN SARAN}

Peningkatan kualitas proses tampak pada kualitas pembelajaran. Sikap yang ditunjukkan mahasiswa dari kegiatan pretes, perlakuan hingga postes memperlihatkan sikap yang berbeda. Setelah diberikan perlakuan mahasiswa lebih 
aktif dan kondusif dalam mengikuti kegiatan pembelajaran. Sikap mahasiswa menjadi lebih reaktif terhadap pembelajaran. Mahasiswa tidak hanya diam mengikuti instruksi pengajar, namun juga menunjukkan minat atau antusias yang tinggi pada saat pembelajaran. Semangat siswa lebih terlihat setelah adanya perlakuan. Kemampuan mahasiswa dalam menjelaskan juga secara tidak langsung dapat terlatih dengan baik dengan adanya presentasi individu.

\section{DAFTAR PUSTAKA}

Arief, Ermawati dan Yarni Munaf. 2003."Pengajaran Keterampilan Berbicara: Buku Ajar". FBSS: UNP Press.

Sagala, Syaiful. 2005. Administrasi Pendidikan Kontemporer. Bandung: Alfabeta. Sugiyono. (2007). Metode Penelitian Pendidikan. Bandung: Alfabeta

Taniredja, Tukiran. 2013. Model-Model Pembelajaran Inovatif Dan Efektif. Bandung: Alfabeta.

Uno, Hamzah. B. 2011. Belajar Dengan Pendekatan Pailkem. Jakarta: Bumi Aksara.

Wahyuni, Sri \& Syukur, Abd. (2012). Asesmen Pembelajaran Bahasa. Bandung: PT Refika Aditama 